\title{
Constructing the self in later life: The life story of Selaelo Thias Kgatla (1949-)
}

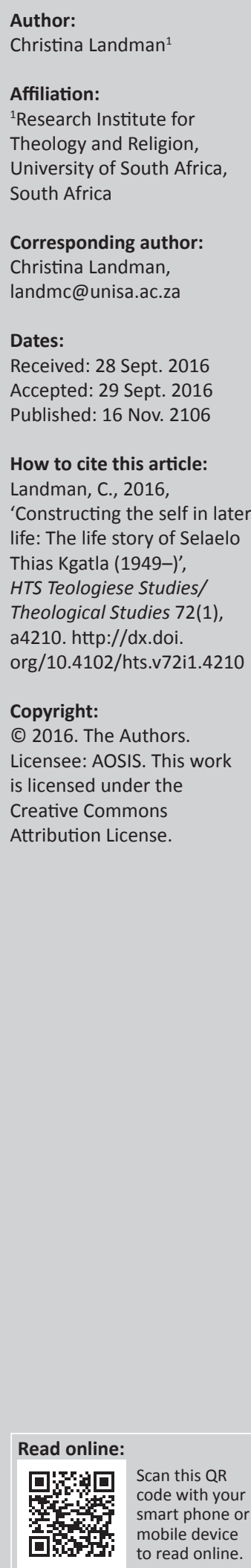

On 15 April 2014 the author conducted an interview with Selaelo Thias Kgatla (then 64) by means of a prearranged interview schedule to revaluate a life review. Kgatla's years of academic and ecclesiastical involvement leading to his ordination as the minister of the Polokwane Uniting Reformed Church in Southern Africa at the age of 47 were considered. However, the focus was on the last 18 years before his retirement, which was to happen in December 2015. This period commenced with his ordination in 1997 and covered his involvement in church leadership as Assessor and later Moderator of the Northern Synod (since 1999) and as Moderator of the General Synod (since 2005), as well as his appointments as professor at the University of Limpopo in 1997 and at the University of Pretoria in 2010.

In freezing this interview into the academic account given here, oral history and methodological sensitivities are considered. The interviewee's ownership of his life review is acknowledged; his construction of the self as a coherent story of church leadership is respected; and the characteristics of remembering in later life are pointed out reverentially.

The life review with Kgatla was expanded with interviews from colleagues and congregants of his choice who confirmed the construction of his life story as one of relationship and resistance. Finally, the author gives a concluding overview of aims achieved in the article in terms of oral methodology and the contents of a life review in which the interviewee constructed his life as a church leader on the interface between resistance and relationship.

\section{Introduction}

\section{Aims and sources}

A leader knows when to resist and when to relate.

The aim of this article is to revaluate the life story of Selaelo Thias Kgatla in terms of his construction of the self in later life. The article addresses this self-construction of leadership as one of persistent choices between resistance and relationship. These were choices made in contexts of conflict as Kgatla took on leadership positions in the Uniting Reformed Church in Southern Africa (URCSA) as Moderator of the Northern Synod of URCSA (2003-2014), Moderator of the General Synod of the URCSA (2005-2012), minister of the Word in the Polokwane URCSA (1997 till demission on the grounds of retirement on 14 March 2015) and professor of Theology (1997-2014) at the Universities of the North ${ }^{1}$ and Pretoria.

Kgatla gave expression to both these leadership values of resistance and relationship in academic articles of the past 18 years. His resistance was, and is, against racial oppression, especially as it was embodied in the forced removals of the mid-20th century in South Africa (Kgatla 2013a:120-132). In addition, his resistance was in his own church, against the dependency of the black church on the white Dutch Reformed Church (DRC; Kgatla \& Saayman 2013:1-9). In contrast, he relates to the poor and the vulnerable and even to the 'witches' whose prosecution he exposes as fears of a society in transit (Kgatla 2012:52).

In the articles mentioned, Kgatla expresses himself in a mixture of the pietistic language of the liberation theology of the 1980s and the academic language of the theologies of the day. He connects to the poor and vulnerable in the pietistic-liberationist categories of 'God's preferential option' and 'prophetic justice', while analysing faith communities in terms of the recent theological insights of 'intersectionality', a term used to undermine the simplistic categorisation of people into race, gender, age, class and sexual preferences (see Kgatla 2013b:1). When interviewed,

1.Now the University of Limpopo. 
Kgatla as moderator of a Reformed church intersected between Reformed church language, pietistic modes of expression and academic insights, thereby identifying these three entities as the sources of his leadership of resistance and relationship.

These entities came to the fore in a 5-hour long interview with Prof. Kgatla in dialogue with the author, which is the main source of this article. It is extended with interviews with four of his congregants at Polokwane URCSA. Those interviewed were selected by Kgatla himself and claimed him as the role model for their own achievements. They are Letlodi Mafokoane, Refilwe Mashilo, Mmipe Mokgehle and Simon Mashao. Added to these are those informally interviewed by the author - and by the choice of the author, chosen on no other grounds than that they are known to have been close to Kgatla. They are Rev. Hendrik Moima, Assessor of the Moderamen of the Northern Synod (2011-); Kgatla's wife Constance Kgatla; Prof. Klippies Kritzinger, now retired from the University of South Africa; and Alet Pretorius, who worked with Kgatla as scribe of the Northern Synod since 2003.

\section{Methodology}

Central to the oral history debate worldwide stands the question of whether oral history sources should be subjected to the same values of validity, truth and objectivity as was traditionally required by methods of historical investigation. Especially in the case of biographical interviews, oral historians differ as to whether facts should be checked or whether the integrity of every story told should be honoured unconditionally.

Narrative inquiry, as described by Clandinin (2007) in a variety of essays, identifies three main ways of 'interpreting' oral history interviews. One way is to identify dominant themes in the interviews that connect them to one another and to the overall theme of the research. A second method is to expose the personal agendas of the interviewee(s), be they political, economic or social, racist or sexist. Thirdly, and what is preferred by narrative inquiry, is to relate the contents of the interviews in an unmediated way, that is, without checking facts or looking for concealed agendas.

This article, then, presents the interviews with Kgatla and the significant others he has chosen unmediatedly around the themes of resistance and relationship. The reason for choosing a method that focuses on themes without mediating the contents is to highlight the way in which Kgatla has chosen to construct himself as church leader. Immediately, of course, Julie Cruikshank (in Llewellyn 2015:211) comes to mind; she undermines the idea that stories speak for themselves. Stories, Cruikshank insists, become facts and find voice only through theoretical assistance.

Acknowledging that the academic presentation of interviews requires at least a minimum of 'theoretical assistance', three further notes on methodology are to be made here in reference to phrases used in the title of this article.
The first remark is on the methodological challenges of 'remembering in later life'. People remember differently when they are young from when they are at the end of their careers. One can point to three distinctive ways in which people remember when looking back. Firstly, they revaluate and award value to their lives through their attachment to a specific agency, such as the church. Secondly, they synchronise their life events to form a meaningful and rational whole. Thirdly, their life narratives speak towards the criticism of those they have experienced as enemies and critics. Here, in accordance with the insights of Joanna Bornat (2011:202), it will be used as a method producing positive results in that Kgatla's life review is described as a life leading to social change in the URCSA.

A second remark is on the 'construction of the self' as presented in the title. Kristina Llewellyn (2015:153) points out that, although the interviewer acknowledges that the interviewee is not giving 'facts' but a (re)construct of his or her life, the oral historian remains subject to the selfexpression of the interviewee. Although people's narratives are socially constructed, the narratives are nevertheless to be respected as their own stories, even when they express what the interviewer does not want to hear. This author hereby confirms her respect for the way in which Kgatla constructed himself in later age as a coherent self that has moved through history with a single identity, namely that of church leader.

Finally, it has to be re-emphasised that the method used here is not one in search of objectivity. It seeks to freeze Kgatla's story in the self-expression of the interviewee, supported by the testimonies of supporters. 'Freezing the walking voice' is a method within oral history described by Landman (2010:287) as having a threefold focus. Firstly, ownership of the story is given to the interviewee, and his perspectives and contributions to indigenous knowledge are highlighted. Secondly, sensitivity is displayed in contextually and culturally bridging the inevitable distance between interviewer and interviewee by giving extra care to explaining the context and culture of the interviewee. Thirdly, the emphases given by the interviewee are blended with the overall aim of the interviewer, which, in this case, is to freeze the story of the interviewee as a story of resistance and relationship.

\section{Structure}

Consequently, this article has the following structure: The first part of the article contains the story of Thias Kgatla from birth to academic and church leadership. This story will be chronologically driven, intertwined with issues of the time, as prioritised by the interviewee. The second part contains the interviews with several interviewees who were influenced in their own leadership paths by Kgatla. The third part deals with the specific issues of resistance and relationship that were negotiated between the interviewer and the interviewee, namely, leadership, Belhar, church unity and Turfloop. A conclusion summarises the highlights of the story thus frozen. 


\section{The life and times of Thias Kgatla Preparing for church leadership: The first 47 years, from 1949 to 1997}

Thias Kgatla was 47 years old when, in 1997, he was licenced and ordained in the Polokwane congregation of the URCSA. A mere 2 years later, in 1999, at the first Synod meeting he attended, he was elected Assessor of the Northern Synod, and in 2003 he was elected as its Moderator, the highest position of church leadership at regional synod level. He remained in this position for 12 years until his retirement in 2014. In 2005 Kgatla also became the Moderator of the General Synod in which he remained for the two periods of 4 years each that are allowed by the church's church order. It was in effect only a period of 7 years, due to the fact that the General Synod was called in 2008 after a period of 3 and not 4 years.

Having been ordained at a relatively late age and having entered church leadership shortly after his ordination, the following questions may appropriately be asked.

\section{Where did Kgatla come from?}

Selaelo Thias Kgatla (interview 15 April 2014) was born on 20 December 1948 in Bochum (also known as Senwabarwana), a small village $100 \mathrm{~km}$ northeast of Polokwane (then Pietersburg) in the Limpopo Province. The village was 'founded' by German missionaries who had worked in the area since 1872. His parents did not belong to a church, although his mother spent some time with the Lutherans after her confirmation in the Lutheran Church as a schoolchild. Kgatla was 18 when he joined the Dutch Reformed Church in Africa (DRCA) in 1968 at the accepted age for confirmation in this church. The DRCA was the 'black daughter church' of the apartheid DRC of Southern Africa. In 1994 the black DRCA united with the coloured Dutch Reformed Mission Church to form the URCSA, of which Kgatla was to become a minister of the Word and eventually the Moderator at both regional and General Synod level.

However, as a young boy Kgatla was interested in religion even more than the missionary practice expected from him. He joined the Dorothea Mission near Pretoria after school. He did not stay long, though, since he found this institution to be too fundamentalistic in their use of the Bible and focused only on 'winning black souls while the country was burning'. In 1976, then, the year of the Soweto uprisings, while working for Lebowa, he commenced with his undergraduate studies at the University of South Africa (Unisa), a distance learning university. People warned him that Unisa was 'communist' (interview 15 April 2014), but at this university he was greatly influenced by the local liberation theologians of the time, David Bosch and Adrio König. Incidentally, they were both white male Afrikaner ministers of the DRC who, at great personal cost, tried to reform the white church from within. He then also majored in the subjects that they were heading as professors, which were Missiology and Systematic Theology, respectively.
After finishing his BTh (Baccalaureus Theologiae), he enrolled for an honours' degree, where he studied with Prof. Inus Daneel, an internationally well-known authority on the African Independent Churches.

Kgatla was aiming for the ministry. Yet, at the time the DRCA did not acknowledge Unisa's training when licencing students. Black ministers for the DRCA were trained, inter alia, at Turfloop at the (then black) University of the North in Polokwane (Pietersburg). This was full-time training. In the 1980s Kgatla already had two children with Constance, whom he married in 1976, and full-time class attendance was not possible. However, he simultaneously through distance education enrolled for courses in business economics and marketing management, which later as a pastor equipped him greatly for congregational and synodical leadership.

In 1987 Kgatla was appointed a lecturer at Stofberg at the University of the North, just as he was enrolling for a master's degree in Theology at Unisa. The next year he completed his master's under the supervision of Prof. Klippies Kritzinger with the title 'Dutch Reformed Church Mission in Northern Transvaal, 1865-1964: A critical evaluation of motives, goals and methods'. Kgatla himself evaluated his work as 'too critical':

I wanted to know why the Dutch Reformed Church did mission. They did not do it when they first came to the Cape. It started late. There were three waves of Dutch Reformed Mission. The one was in 1862. They sent someone to Saulspoort and another to Kranspoort. They sent people to determine the future of the lives of black people. Maybe I was too critical of this ... (T. Kgatla, pers. comm., 15 April 2014)

On the day that Kgatla graduated in 1988, 'we were coming from the Theo van Wijk Building at Unisa when I met that tall guy, David Bosch'. Because of distance education, Kgatla had not previously met with Bosch in person. 'I said to him, I am looking for a supervisor for my $\mathrm{PhD}$, and he jokingly said: "Let's all search for him"'. In 1992, Kgatla graduated with his first PhD under the promotorship of David Bosch, entitled 'Conformity, change and conversion among the Northern Sotho people: Towards a missiology of self-transcendence'. Kgatla remarked (interview 15 April 2014) that this was a topic initially suggested by Bosch, and he concurred with that in spite of the fact that, at the time, there was a lot of pressure on black theologians to work on Black Theology. The supervisor for his master's, Klippies Kritzinger, dedicated his own doctoral thesis to Black Theology (Kritzinger 1988). From a black perspective, then, the thesis was not received well. Kgatla described this reaction, and his counter-reaction, as follows:

I sympathised with black theologians like (Itumeleng) Mosala, and (Takatso) Mofokeng, and Buthi Thagale. But I concurred with (Simon) Maimela who had a balance: God was on the side of the oppressed, and there were some things that were terribly wrong. Apartheid was an evil system, but we must also remember that we have evil things among black movements. So that was my thesis: I said, let us go beyond ourselves. There is a paper Willem Saayman wrote and delivered at our gala dinner 
last year (the Northern Theological Seminary gala dinner 2013). He admitted that I was correct in my observations in 1992, although many people then thought I was too soft on the white people. All I did was to ask whether the missionaries changed black people? And if they did, did they change them for good or for bad? Was it not conformity? Did the black people not only conform with what the white people wanted? But I did not really come up thoroughly and convincingly on the issues of conformity, change and conversion. But, you know, in the 1990s people tried to be relevant. Part of my thesis was empirical. I interviewed with a questionnaire the Northern Synod of the Dutch Reformed Church in Africa, choosing congregations randomly. I then said, I must also interview congregations of the ZCC (Zion Christian Church) to try to see what is different, where do they differ from the DRCA on conversion. My conclusion was that there were no differences between the ZCC and the DRCA on conversion and conformity. The white missionaries did not want to teach the black people in such a way that they get out of hand. They wanted to teach them and still control them. They want them to conform. And I said the same pressure was applied on the ZCC.

At this stage, Kgatla was strongly focused on getting ordained in the DRCA as a minister of the Word. His theological and business studies, as well as his work as an elder in the Lebowakgoma congregation, where he and his family lived, pointed to this aim. He applied for licensing in 1986 but in spite of becoming a lecturer at Stofberg Seminary itself, he was denied licencing for 10 years. Kgatla remembered (T. Kgatla, pers. comm., 15 April 2014) that the Moderator of the time, Rev. Maphoto, said that Kgatla would become a minister 'over my dead body'.

Kgatla was seen as dangerous by the church authorities. One reason was his role in the afstigting [secession] of the Lebowakgomo congregation.

J.R. Phatudi (1977) wrote a master's dissertation on the secession of Lebowakgomo in which the role of Kgatla was described as one of needed initiative and church orderliness. Kgatla himself explained (interview 15 April 2014) that the need for secession was based on the enormity of the Lerato congregation, which stretched from Potgietersrus (now Mokopane) to Lydenburg over a length of $75 \mathrm{kms}$. After all the necessary church orderly steps were taken for secession, it was blocked by a local minister, who apparently feared for his salary, claiming that afskeiding is egskeiding [secession is divorce], and eventually by the Moderamen of the Northern Synod (then Northern Transvaal) itself. Kgatla's unpopularity with the church authorities grew with him leading the newly founded Lebowakgomo congregation to stop the Synod from constituting at its meeting in 1991 through a court order if Lebowakgomo was not recognised by Synod as an independent congregation. Eventually Lebowakgomo was registered by the scribe, Dons Kritzinger, and was thus recognised as a congregation.

Because of those experiences, Lebowakgomo became a very, very powerful congregation. Even now when you look at the Synodical heffings [contributions], you will see that they have contributed more than R950 00.00 this year. They are highly motivated. They are highly focused. This is the type of congregation I would like to see, Kgatla said. (T. Kgatla, pers. comm., 15 April 2014)
In 1994, with the coming of an all-inclusive democracy to South Africa and the opening up of previously white land to black ownership, Kgatla moved with his family - by now his family was complete with four daughters - from Lebowakgomo to Polokwane (then still Pietersburg), and to Polokwane congregation. Previously he had to travel $97 \mathrm{kms}$ to teach at Turfloop. Now it was $30 \mathrm{kms}$. In Polokwane congregation, situated in Seshego 'Township', he was soon elected as elder. He found two ministers there who were fighting with one another 'like cat and dog'. 'There was nothing going on in that congregation. Also, they had a huge, huge debt' (Kgatla, interview 15 April 2014). When the one minister died, this minister himself had specified that the other might not attend his funeral. Also, when he died, Kgatla, who was licenced in 1997 after a 10-year struggle as described, was called to the congregation. Thus Kgatla was ordained in Polokwane congregation on 27 July 1997. He was 47 years old.

Kgatla's election to church leadership soon after he became a minister in his late forties, then, seemingly comes without surprise. He was well-known among members of both the laity and the ministry for his involvement in the Lebowakgomo congregation from the time of its inception in the early 1990s, as well as in the Polokwane congregation from 1994 onwards. He was also known among academics and for his academic studies from 1976 onwards. After 1987 he was known as an academic himself. However, in interviews with congregants, who themselves were community leaders in education and who are cited later in this article, Kgatla is remembered for his leadership, his knowledge of church polity, his hard work in physically and financially building the church, and his (Reformed) spirituality - and not so much for his academic work.

The next section specifically looks at Kgatla's leadership at congregational and synodical level during the 18 years before retirement. This includes the interview with Kgatla, church council members, synodical colleagues and his wife as sources.

\section{The 18 years before retirement: 1997 to 2014}

In narrating his life during his 30 s and 40 s as described in the previous section, Kgatla has constructed himself as minister seeking as a matter of priory and as resisting structures that were - according to his view illegitimately - blocking his way. His life story is one of relating and resisting: He related to charismatic institutions such as Dorothea Mission, but resisted its fundamentalism and its tendency to concentrate more on soul-seeking than on addressing the needs of society. He related to liberation theologians such as David Bosch and Simon Maimela, but resisted black theologians who forced him into a position that he regarded as 'unbalanced'. He related to liberative 'missionaries' such as Nico Smith, but resisted the missionary policies of the DRC that were based on the policy of apartheid. Above all, he resisted letting insults become part of his construction of the self. 
While aspiring to become a minister of the Word, Thias Kgatla summarised his vision for ministry as follows:

I did not want to see the DRCA as a second-hand church in Africa. I want to be a minister to show that the DRCA can be a proudly self-sufficient church. (T. Kgatla, pers. comm., 15 April 2014)

Was he able to realise this goal after he became a minister of the Word?

On 27 July 1997, Kgatla was ordained and inducted in the Polokwane URCSA at the age of 47 years. The congregation, in which he had already been involved for a number of years, posed a huge challenge to his leadership abilities. The congregation had a huge debt and had owed levies to the Synod for 16 years.

Kgatla changed this situation. Where the income of the congregation was R37 000 during 1996, it improved to an astounding R258 000 in the financial year 1997-1998, which is an increase of about $700 \%$. This tendency continued so that in the financial year 2013-2014 the income of this congregation was R2.4 million. Under his leadership, 10 churches and halls were built with a joint value of about R33 million, excluding the value of the land. His latest and most impressing building project is the Serala View Church Complex, which was inaugurated on 3 August 2013 and valued at about R16 million.

Kgatla warned the Church Council that the budget was not going to be met and that people would not give money when they felt that they were being milked or taken on a guilt trip. Eventually, congregants gave money to the church because they felt loved; as Kgatla explained:

\footnotetext{
I said to the church council ...Whenever you see me preaching, you must ask yourself what is my objective. Am I just preaching to entertain people? I mean I am preaching in order to change the lives of people. (And when you go on home visitations, you must) know those people by names, you know their children, what their children are doing, you know everything. So that you understand them ... we created a conducive atmosphere where people will feel that the church is loving and that the church is the place to rest and all that. Now because of that change of leadership and leadership style, people came forward to give money. And I said people did what they did because they hear there is a new minster and he is a professor at the University and his sermons are different from what you hear and he reads books, he consults books. He puts his sermons sometimes on overhead projectors and all that, people were getting excited. They never had these kind of things before. I must say ..., but I am not apologising for my training. I will in a humble way serve people. (T. Kgatla, pers. comm., 15 April 2014)
}

In spite of his enormous commitment to the congregation, Kgatla finished a second doctorate in the year 2000 under the supervision of Prof. Kobus Krüger and Prof. Gerrie Lubbe. His thesis was on witchcraft and was entitled, Moloi ga a na mmala (A witch has no colour): A socio-religious study of witchcraft accusations in the Limpopo Province. During the interview of 15 April 2014, Kgatla, having constructed himself both as a caring church leader and ruthless academic, spoke at length about his investigations into witchcraft in the
Limpopo Province. In doing so, he constructed himself as a community leader. During his research he interviewed not only those victimised by threats of being a witch but also the perpetrators, engaging in a campaign to make the community aware that witches do not exist and to confront them with their fears during the times of transition and uncertainty that had led them to accuse innocent people of their misfortunes.

\section{Kgatla as Moderator of the Northern and General Synod}

In 1999, two years after he had been ordained as minister of the Word, Kgatla was elected as Assessor of the Northern Synod, and during the next Synod in 2003 as Moderator. People came to know how he turned Polokwane congregation around. They trusted him as their Moderator. This also happened at national level when, shortly afterwards in 2005, he was elected Moderator of the General Synod of URCSA. This was much to his surprise (T. Kgatla, pers. comm., 15 April 2014), since he won against Alan Boesak, who then became the Assessor. He remained in this position for two terms, that is, till 2012. He upheld this position during his appointment as professor at the University of Pretoria in Science of Religion and Missiology in 2010.

\section{What made Selaelo Thias Kgatla such a special leader?}

Alet Pretorius, who served two terms with Kgatla on the Moderamen of the Northern Synod, was interviewed on 04 May 2014 at her house in Silverton, Pretoria or Tshwane. She listed the following as characteristics of his outstanding leadership. He was always prepared and in time for meetings and was extremely disciplined. His vision was to make URCSA better, and he was persistent and focussed to achieve this vision. When he was convinced that he had taken the right decision, he would not deviate from it. He set an example of how to serve the church. He served the church with all his talents, including as an academic. He was a shepherd who was not afraid to lead and who took the congregations and presbyteries along with him. He was a devoted family man who also had the church as a spiritual family. He was honest and straightforward. He did not tolerate backbiters or twofaced people and he never was one himself. He furthermore did not tolerate laziness and incompetence. He stood for justice in the church and society. He was respected by people, by a majority of URCSA members, but also outside the church as a theologian. He felt himself called by God to serve the church but did not take the glory for himself. He was supportive of others and gave advice to whoever needed it. He was the Moderator of the Northern Synod for three terms, and the Moderator of the General Synod for two terms. As such he played an important role in the unity talks between URCSA and the DRC. Ultimately his vision was to give URCSA its rightful place among other churches.

These qualities were reiterated by Rev. Hendrik Moima (interviewed on 2 May 2014 at the Dienssentrum in Mamelodi), who was a student at Turfloop when the much 
older Kgatla, then a theology student at UNISA, made use of the Turfloop library. Later (2010-2014) Moima was to serve as Assessor in the Moderamen of the Northern Synod with Kgatla as Moderator. Moima remembers Kgatla the Moderator as a workaholic, a man with integrity, a humble man, who dedicated himself fully to serving the church.

Prof. Klippies Kritzinger, interviewed in his office at Unisa on 16 May 2014, summarised his construction of Kgatla in the following words after working with him in the URCSA leadership for many years: 'Kgatla is hardworking and disciplined, a leader of strategic excellence. In short, he is a spiritual and self-propelled church leader, and a community engaged academic'.

During his interview, Kgatla did not construct himself as a family man, probably because the prearranged interview schedule focussed on him as a church leader and to a lesser extent as an academic. He mentioned once in this interview that he was married with four daughters. Alet Pretorius remarked in her interview that Kgatla was a committed family man, and this warranted an interview with Kgatla's wife. Constance Totone Langa Kgatla was interviewed on 3 May 2014 in their home in the inner city of Polokwane. She was born on 22 January 1953 in Amsterdam near Piet Retief in Mpumalanga, South Africa's most eastern province, to a Zulu mother and a Pedi father. She moved with her father to Mokopane where she attended Setotolwane High School. One of her co-learners was Thias Kgatla. After school they were both working as admin clerks for the Lebowa government. They both started studying part-time, she in Education and he in Theology. Coming from 'an unstable and violent family', she had decided never to marry and never to trust men. However, Thias Kgatla eventually convinced her otherwise, and in December 1976 they were married by a magistrate, a marriage that was celebrated and blessed in church in April 1977. At the time of the interview they had been married for 38 years and parented four daughters, Thato (b. 15 January 1978), Lebogang (b. 19 April 1981), Morongwa (24 August 1986) and Phethego (b. 9 November 1991). Today Constance works for the Limpopo Education Department as subject advisor, with an honours in Psychology from Unisa, an honours in Biblical Studies also from Unisa, and a master's in Development Studies from the University of Limpopo. A church leader in her own right, she has been on the Executive of the Christian Women's Movement (CWM) of the Northern Synod for two terms. When asked to describe the features that characterised Thias Kgatla's leadership, she answered: 'Two things. His love for the Lord. And he will put everything in if he believes that is the right thing to do'.

Kgatla himself chose four church council members to be interviewed as co-constructors of his identity as leader on the interface between relationship and resistance. Here follow their testimonies of how Kgatla influenced their own leadership styles as leaders in the church and in the community.

\section{Kgatla's influence on the leadership style of congregants Mr L.P. Mafokoane}

Letlodi Peter Mafokoane was interviewed by the author on 3 May 2014 at Polokwane URCSA, Serala View. At the time of the interview, Mafokoane was chair of the Support Ministry for Finance and Administration in Polokwane URCSA, although he was not a financial expert by profession but a teacher in English, History and Agricultural Sciences. Born in Zebediela, he grew up near Turfloop and raised his children in Seshego, being a member of the DRCA and URCSA his whole life. He came to know Kgatla 2 years before the latter came to Seshego in 1997. He called Kgatla a 'visionary leader'. Kgatla was the twelfth minister of Polokwane, but the first one with a vision - according to which he drove the congregation relentlessly, of course, as a God-loving person, according to Mafokoane. Kgatla was purpose-driven and able to communicate this purpose to the congregation. He was committed, 'a slave to the work of Jesus Christ'. So hardworking was Kgatla, Mafokoane said in a lighter vein, that his wife wanted to lay a charge at the Church Council that the Church Council should discipline him for overwork. His example spoke loudly, and thus he influenced people to follow his vision - however harsh he was on people who differed from him or did not contribute adequately to the congregation's funds. In Kgatla he saw something he had never seen in a minister before, Mafokoane said, something he could not imagine. He saw Kgatla opening a blocked sewer with his own hands. He saw Kgatla being a teacher and a student, a scholar and a fighter for the church within the Bethesda Presbytery, where Kgatla sometimes feared for his safety. Kgatla also saw something in Mafokoane to make him the chair of finances. In 1 year, from 1996 to 1997, the income of the congregation rose from R36 000.00 to R258 000.00 - in a year when the white DRC withdrew their stipend for the minister from the congregation. Kgatla led the congregation out of its dependency syndrome - and for that he was called by the chief executive administrator at the time, Dr Hennie Möller, the 'Moses of Polokwane'.

At the opening of the Serala View Church Complex of Polokwane URCSA on 03 August 2013, Mafokoane listed the 10 church buildings built by Kgatla ${ }^{2}$ - with a joint value of R33 million excluding the value of the land - as follows:

- Blood River church building: 04 December 1999, valued at R725 000.00

- S.T. Kgatla Hall (Seshego Zone 2): 05 December 1999, valued at R8 515000.00

- Ga-Mashashane (Ga-Kgasha) church hall, 02 December 2000, valued at R612 000.00

- Ga-Maja church building: 03 December 2000, valued at R1 720000.00

- Seshego Zone 1 church building: 28 October 2001, valued at R3 235000.00

2.Valued by Francois Goosen of Theo Goosen, registered professional valuer and estate agent. 
- Newland (Ga-Mashashane): 23 August 2003, valued at R640 000.00

- Ga-Chuene church building, 24 August 2003, valued at R982 000.00

- Ga-Teffo church building (renovation): 21 July 2007, valued at R700 000.00

- Seshego Zone 2 church building (extension and renovation): 22 July 2007, valued at R8 515000.00

- Serala View Church Complex: 03 August 2013, valued at R15 800000.00

\section{Mr R.R. Mashilo}

Refilwe Ramadumetja Mashilo, too, was interviewed by the author on 03 May 2014 at Polokwane congregation, Serala View. Born in Ramatwala, Mashilo today is the headmaster of Mmamarama Secondary School. Scribe of the Church Council of Polokwane at the time of the interview, he was a member of the Church Council in 1997 when Kgatla was called as minister. Kgatla had to unite the congregation after previous struggles between the ministers. He did more than that. He provided the congregation with a vision and a strategic plan that laid their fears to rest and empowered them to great financial heights - all without a trace of self-enrichment:

He helped us to think outside the box. Moreover, he helped me to become a principal. I copied his management style, working in a team, making space for fears to be expressed, taking collective decisions.

There are so many things to mention, Mashilo said, that he could only summarise the high points. These include Kgatla's building projects, his boosting of the finances, his preaching and training of the congregation, and his good relationship with all age groups in the congregation, engaging the youth in the liturgy and especially in presenting the Confession of Belhar to the congregants. The church hall at Seshego Zone 2, as well as the auditorium of the church in Serala View, are named after Kgatla. In summary, Mashilo said, Kgatla is a morally strong man, with no idle time.

\section{Mr M.G. Mokgehle}

Mmipe George Mokgehle was interviewed by the author on 3 May 2014 in a restaurant in Polokwane. Mokgehle was a teacher in Mathematics, Afrikaans and Technology. He described Kgatla as a person on the interface between being dedicated to his people on the one hand and insisting that they should follow his vision; a pastor on the interface between patience and passion. Kgatla was a hard worker, one with integrity, one who allowed everybody to have a say and who did not make plans and then pass the ball to somebody else to do the work. Everybody was to play, with Kgatla overseeing that the goal was scored. Mokgehle once saw Kgatla digging the foundations of a church (one of the 10 he built) with his bare hands. He learned from Kgatla to love what you are doing and to love giving to the Lord from the fruits of what you love doing.

\section{Mr S.R.M. Mashao}

Mr Simon Mashao was interviewed by the author on 16 May 2014 in the Spur Restaurant in Midrand, where he was waiting while his wife was undergoing treatment at a nearby hospital. Mashao was 71 years old at the time of the interview and had been retired for 10 years. He was an inspector of schools. He had known Kgatla since 1993 and was at the time of the interview the chair of the Core Ministry for Proclamation and Worship of the Polokwane Church Council. Leaders, according to Mashao, are either born or made, and Kgatla was a born leader. Mashao referred to Kgatla using terms such as restless worker, dreamer, visionary, motivator, workaholic, an energetic and purposeful person with an insatiable drive and one who leads by example. When Kgatla came to the congregation, his first priority was to finish the incomplete church structures in the wards; his second priority was to build churches in wards where there were none. His third priority was to renovate and extend existing church structures; fourthly, he wanted to complete the Serala View Church Complex. He accomplished these goals by rationalising the congregation's sources of revenue and having an effective church council elected. In those days there were 100 congregants serving on the church council, representing nine wards. Regular church council meetings were held and work was done according to an annual plan. The church council was trained in church polity. Kgatla accomplished everything in an orderly way, without self-interest, sharing his knowledge and skills, always prepared and ready to learn. He was committed to his synodical work and invited many ecumenical guests who were accommodated by congregants, people from Belgium, the Netherlands and Germany. Yet according to Mashao:

Kgatla's life was not a smooth journey, it was tough, on all levels, from the congregation, the presbytery to the synod. But he managed. In a sense his life was like a golden thread, led by the ambition to do God's will.

That then, was also Kgatla's main influence on him: Kgatla made him grow spiritually - through his sermons, his knowledge and his encouragement. Finally, Mashao presented a list of 14 principles according to which he believed Kgatla worked: (1) transparency (in finances); (2) participation (for everybody); (3) accountability; (4) commitment; (5) integrity; (6) purposefulness; (7) competitiveness; (8) good governance; (9) professionalism; (10) enthusiasm; (11) volunteerism; (12) delegation of power; (13) orderliness; and (14) acknowledgment of people, their joys and their sorrows.

The above interviewees, chosen by Kgatla, made a contribution to his self-construction by depicting him, at congregational level, as excessively hardworking and purpose-driven. In terms of relationships he is acknowledged as a team worker who won people's confidence by relating to what they regarded as important in their personal lives. In terms of resistance Kgatla was seen as not deviating from his vision and being harsh with those who did not support him. Finally, then, Kgatla in the latter part of his interview 
(15 April 2014) was asked how and with whom he related, or whom did he resist, vis-à-vis four areas of conflict in the life of the church with which he journeyed as minister and moderator, namely leadership, the Confession of Belhar, church unity with the white DRC, and Turfloop.

\section{Issues of resistance and relationship}

According to the prearranged interview schedule, Kgatla was asked to comment on four issues for which he was known for both relating and resisting. The first of these is leadership. All the congregants interviewed in the above focused on Kgatla's leadership skills, which they experienced as both visionary and practical but also strict and harshly applied. Kgatla himself gave a much more humane view on leadership vis-à-vis himself during his interview (15 April 2014). He was chosen as Moderator of the General Synod in 2005, winning against Allan Boesak and following in the footsteps of James Buys. He was taken by surprise, and said 'I think it was what people heard I was doing as a minister'. As leadership skills he mentioned humility, sincerity, resilience, hard work, transparency, integrity and trustworthiness. Resisting popularity, he mentioned decision-making as one of the main characteristics of a leader. 'Leadership is about taking decisions ... If you want to be popular, indeed you must not take decisions'. However, decision-making comes only after listening. He learned this from David Bosch, who said to them as students: 'The only reason why you should study theology, should that you want to listen'. Even more than others, a leader should be a good listener.

Kgatla did not speak much on the second theme, that of the Confession of Belhar, probably because he accepted it as a given and had not been part of the build-up to its acceptance in 1986, at which time Kgatla was not even a minister of the Word. However, it was the congregants interviewed in the above that noted Kgatla applying, confessing and explaining the Belhar Confession to the congregation.

The third theme was church unity. Kgatla told this as a story of relating to the dream of unity between the white DRC and the black URCSA and at the same time resisting self-centred and unethical behaviour from both churches. When Kgatla became Moderator of the Northern Synod in 2003, a 'unity convent' was held with the Northern and Eastern Synods of the DRC. Kgatla related to people like Nelus Niemandt and Kobus Gerber from the DRC in the negotiations, while others from other synods of URCSA, such as Zach Mogoebo, James Buys and Mary-Anne Plaatjies, were suspicious about the unification process. Kgatla's position was to always give people a chance to prove themselves first. During the interview he said that he suspected that it was his reconciling attitude that won him the Moderatorship of the General Synod in 2005. He continued with unification talks until 2007, when, indeed, the attitude of the then-Moderator of the DRC, Prof. Piet Strauss, convinced him to call for a moratorium on unity talks. In his interview Kgatla explained the reasons for the moratorium as follows:
You know, they ... sjoe! They came with things. I mean this is the problem sometimes, well always with the Dutch Reformed Church, that they take it for granted that things will go their way. They came up with many questions about how difficult it is, 'our members are not accepting, our members are asking about finances, our members are asking about the language, our members ...'. You know! They came with a long list! And then I immediately changed and I said no. This is not what I have been understanding to be a problem. We were always saying that we are going to tackle problems together. We know your problems. We have problems. Together we should solve those problems. Now that is what led to us calling a moratorium. Because we have seen that they are putting many, many questions on the table and those questions will never be solved in this life. (T. Kgatla, pers. comm., 15 April 2014)

Kgatla furthermore made extensive efforts to bring the DRCA, that is, those who did not join the URCSA unification between the black DRCA and the coloured Dutch Reformed Mission Church in 1994, into the union to become part of the URCSA. With resistance from inside the URCSA, he nevertheless assisted in paying off some of the debt incurred by URCSA congregations in the Free State in court cases but was not able to bring the DRCA into the fold. Although names can be mentioned of church leaders who resisted this unification process from both sides, Kgatla remembered the name of one specific person in the DRC in the Free State who played a prominent role in stabilising the relationship, Rev. Gideon van der Watt.

In a continuing story of relationship and resistance, Kgatla addressed the fourth theme of the interview (15 April 2014), that of Turfloop. Turfloop Seminary, attached to the University of the North (now the University of Limpopo) used to be the training centre for ministry students in the DRCA and later the URCSA. It closed down in the 1990s, and Kgatla was closely involved in addressing problems ensuing from the closure, namely the disappearance of overseas funding given to save Turfloop, as well as the challenge of saving the land and buildings for the URCSA. Of the four themes, Kgatla spoke most passionately and elaborately on this one. This is a complicated and controversial story that shall only be summarised here - without mentioning names - in order to demonstrate Kgatla's resilience in pursuing a matter that he believed should be brought to justice. In short then, struggles between the pastors of the local congregation led to the community being invited by one of the pastors to occupy the houses at Turfloop previously occupied by lecturers and students. Moreover, R159000.00 received from the Netherlands to save the property went missing. Disputants and occupants landed in court. 'People, URCSA members, tried to make money out of Turfloop because they thought the church was too weak to defend itself ... I just said to myself my survival here is not to trust anybody' (Kgatla, interview 15 April 2014). With meticulous and timeconsuming effort, Kgatla took action and had the occupiers interdicted. They ignored the court order, and Kgatla, reporting them at the police, discovered that some of the members of the South African Police were themselves occupying the houses. Eventually the City Council and the 
municipality were involved, as well as the local chief - all claiming that they owned the land. By the time of the interview, Kgatla was awaiting a court order for the land that was originally given to the church in 1986, to be transferred to the URCSA with a title deed to prove ownership. Talking about the thin line he always had to walk between relating and resisting, Kgatla summarised (interview 15 April 2014) his attitude at the height of the struggle as follows:

Now, I had only one thing in mind: that I was going to fight to the end. My wife was getting calls to tell her that she should speak to me. That I am going to die. They are armed to the teeth and they know where I am working and they know where I am staying and she must stop me. Now I said, no I am not going to stop it. These were some of the things that made people see leadership qualities in me. People said that I was not benefiting and I could just have left it, but I did not. (T. Kgatla, pers. comm., 15 April 2014)

\section{Conclusion}

The article describes how Selaelo Thias Kgatla constructed himself as a church leader in later life, that is, in the year of his retirement in 2014. His construction of the self is one of consistent choices between relating and resisting. In this article his interview was presented in an unmediated way, that is according to his thematic preferences, which he related in a language that presented a mixture of Reformed Church Policy, pietism and academia. Kgatla told his story as that of relating to the politico-pietist theology of David Bosch, while resisting radical black theologies. While resisting church leaders who did not follow his vision, such as in the case of the afstigting of the Lebowakgomo URCSA, he resisted in later life the 'unethical' behaviour of church leaders vis-à-vis Turfloop. At congregational level he showed remarkable skills in empowering his congregation towards fundraising and engaged in almost superhuman building projects. At synodical level he led the way in unity talks that required specialised skills between relating and resisting, while working with church leaders who held a variety of overt and covert agendas.

Selaelo Thias Kgatla's is a story frozen within the realm of integrity, hard work and the constant choices between relating and resisting.

\section{Acknowledgements Competing interests}

The author declares that she has no financial or personal relationships that may have inappropriately influenced her in writing this article.

\section{References}

Bornat, J., 2011, 'Remembering in later life: Generating individual and social change' in D.A. Richie (ed.), The Oxford handbook of oral history, pp. 202-218, Oxford University Press, Oxford.

Clandinin, D.J. (ed.), 2007, Handbook of narrative inquiry: Mapping and methodology, Sage, Thousand Oaks, CA.

Cruikshank, J., 2015, 'Oral history, narrative strategies and Native American historiography', in K.R. Llewellyn, A. Freund \& N. Reilly (eds.), The Canadian ora history reader, Carleton
University Press, Montreal.

Kgatla, S.T., 2012, 'Witch-hunts in modern Africa and early modern Europe (1450-1750)', Studia Historiae Ecclesiasticae 38(2), 49-64.

Kgatla, S.T., 2013a, 'Forced removals and migration: A theology of resistance and liberation in South Africa', Missionalia 41(2), 120-132. http://dx.doi. org/10.7832/41-2-9

Kgatla, S.T., 2013b, 'The transformational, intersectional and transcendental agenda of mission: Quest for a spirituality of the road', in Conference Papers, viewed 24 August 2014, from http://www.asburyseminary.edu

Kgatla, S.T. \& Saayman, W., 2013, 'Across the bridge: Polokwane Uniting Reformed Church of Southern Africa from dependency to autonomy', Studia Historiae Ecclesiasticae 39(2), 1-9.

Kritzinger, J.N.J., 1988, 'Black theology - A challenge to mission', DTh thesis, University of South Africa.

Landman, C., 2010, 'Lindiwe Myeza: Freezing the walking voice', Studia Historiae Ecclesiasticae 38(2), 287-297.

Llewellyn, K.R., 2015, 'Productive tensions: Feminist reading of women teachers' oral histories', in K.R. Llewellyn, A. Freund \& N. Reilly (eds.), The Canadian oral history reader, Carleton Library Series 231, pp. 114-158, McGill-Queen's University Press, Montreal.

Phatudi, J.R., 1997, 'The role played by the church management and the court of law in legitimising the status of Lebowakgomo congregation', MTh dissertation, University of South Africa. 